\title{
The Impact of Tax Collection and Incentives on Economic Growth: Evidence from Nigeria
}

\author{
Abiodun Akanbi \\ Department of Business Administration, Faculty of Management Sciences, Nile University of Nigeria, Abuja, Nigeria \\ Email address: \\ abiodunakanbi1@yahoo.com \\ To cite this article: \\ Abiodun Akanbi. The Impact of Tax Collection and Incentives on Economic Growth: Evidence from Nigeria. International Journal of \\ Business and Economics Research. Vol. 9, No. 4, 2020, pp. 170-175. doi: 10.11648/j.ijber.20200904.12
}

Received: November 23, 2019; Accepted: January 2, 2020; Published: June 4, 2020

\begin{abstract}
The debate on the effectiveness of taxation as an instrument for promoting economic growth remains inconclusive, as several studies have indicated mixed effect of taxation on economic growth. Against this background this study investigated the impact of tax collection and incentives on economic growth in Nigeria. Yearly data for the period $2010-$ 2018 was collected from the Central Bank of Nigeria and Federal Inland Revenue Service. A multiple regression model was used, tax revenue was proxied by actual total tax collected, tax incentives was proxied by foreign direct investment equity and foreign direct investment other capital as independent variables. While economic growth was proxied by real gross domestic product (GDP) as the dependent variable. The data was tested for heteroscedasticity, multicollinearity and serial correlation to examine the robustness of the model. The findings revealed that there is a negative but insignificant relationship between tax revenue and economic growth. The findings also revealed that there is negative but insignificant relationship between and foreign direct investment equity and economic growth. While empirical results confirm that there is a negative and significant relationship between foreign direct investment other capital and economic growth. Given these findings, the study recommends the government to improve on the mechanisms for the collection of taxes to stimulate economic growth. Also, government should grant more incentives to sectors that drive growth, monitor such incentives gather relevant data of the actual amount of incentives relative to the economic growth in other evaluate the efficiency of tax incentives.
\end{abstract}

Keywords: Tax Collections, Tax Incentive, Economic Growth, Multiple Regression

\section{Introduction}

Tax is an obligatory charge levied on the income and properties of individuals, firms and institutions as stipulated by legislation. Taxes paid are not for the direct exchange of good or services but a transfer of resources various economic agents to the government to achieve economic and social objectives. The growth any of country is affected by macroeconomic policies like taxation, investment, government expenditure, exchange rate, interest rate and consumption [4]. Economic growth can be defined as the increase in total production or income in an economy. Every country attempt to increase its revenue base to improve its economy [14]. Tax revenue can be enhanced by the introduction of various tax incentives to motivate the economic agents within the economy to be more productive. These incentives are with the objectives of inducing investments in specific sectors of the economy. Taxation has a direct impact on the government expenditure. Tax revenue is dependent on the level of compliance with tax payments by tax payers and collections by government [10].

A high tax rate can increase the cost of production and reduce the incentive to invest in the economy. While low tax rate in form of incentives can stimulate investment that will lead to economic growth. Taxation also affects the decisions of households to consume, save and work. Workers can substitute activities taxed at high rates for activities taxed at relatively lower rates [6]. Hence high tax rates can make workers to reduce working hours, engage in less productive economic activities which can reduce economic growth. Government policies should be used to ensure that companies should continue to invest in the economy [7]. The relationship between taxes and economic growth is controversial, this is because of tax effect on the decisions made by individuals and firms as well as the direct influence of taxation on the economy as a whole [9]. 
The tax system is closely connected with investment decisions in terms of transparency and fairness [9]. Tax incentives are intended to boost investments in priority sectors of the economy. Tax incentives in Nigeria are in the form of tax holidays, tax cuts, reliefs and allowances, credits and exemptions [14]. Tax incentives are also directed at attracting inflow of foreign investment to complement domestic investments to grow the economy. Tax incentives are deliberate reductions in tax payable granted by the government in order to boost specific economic units to act in some desirable way. Incentives usually stimulate investors to invest more which will lead to an increase in production that will lead to increase employment and productivity. The conflicting results in earlier research on the relationship between taxation collection and incentive on economic growth necessitate this study.

The study covers eight-year period between 2011 and 2018. This paper is divided into five different sections. Section one is the introduction, it captures key elements relating to taxation collection and incentives and the growth of the Nigerian economy. Section two is on literature review. Section three covers the research methodology. Section four focuses on data presentation, analysis and discussion of findings relating to this study. Section five is on conclusion and recommendations based on the outcome of the study.

\section{Literature Review}

This section is in two parts: the theoretical underpinning the study and the review of relevant prior works.

\section{Theoretical Reviews}

There are many theories that support the study of taxation as a discipline. The search for the ideal tax rate where tax revenues and incentives are maximised for social welfare and economic growth has been the essence of the various theories. This study reviewed three main theories.

\section{Ibn Khaldun's Theory of Taxation}

Khaldun theory of taxation has been considered an original and one of his most important contributions to economic thought. According to Khaldun " to perform its responsibilities towards the citizens and the economy, every country needs resources which have to be raised by the government through different means, the most important being the taxes". Khaldun believes that a government should impose low taxes. This stimulates business activities and thus creates more wealth, which makes it possible to collect more taxes. However, rulers tend to increase the tax to benefit themselves. Ibn Khaldun believes that tax rates and tax revenues are two distinct things. A high tax rate is no guarantee that it will maximize tax revenues and collections. Because higher tax rates tend to discourage work effort and encourage tax avoidance and even tax evasion, the tax base will shrink as the rates increases [5]. Taxes also guide the economic behaviour of individuals who can choose work to less if their after-tax income is low which means less saving and investment.

\section{The Laffer Curve Theory of Taxation}

The Laffer Curve is a theory developed by an economist Arthur Laffer to show the relationship between tax rates and the amount of tax revenue collected by governments. Laffer's argument that sometimes-cutting tax rates can increase total tax revenue. The Laffer curve is based on the assumption that in the case of the spendable income increase after-tax, investors make much more investment. Laffer posits [2] that tax rate cuts can increase revenues by improving tax collection and compliance.

\section{The Benefit Theory of Taxation}

The Benefit theory of taxation suggests that the taxes are to be imposed on individuals according to the benefit conferred on them. In effect, the greater the benefits a person derives from the activities of the state, the more he should pay to the government. However, it is impossible to implement this precisely due to the difficulty of determining the number of government benefits, including diffuse benefits such as military protection received by each resident and non-resident taxpayer. It appears more reasonable and just that taxes should be levied on the basis of the taxable capacity of an individual. The major drawback inherent in this theory is the definition of a person's ability to pay and benefit derived. [10]

\section{Empirical Reviews}

A lot of empirical studies have been done on the impact of taxes on economic growth in Nigeria and other countries. Various methodologies and variables have been used with different other results and outcomes. The study reviews the previous empirical work in Nigeria as well as other countries.

In a study [3] found out that there was a significant correlation between taxation and SMEs' growth in Nigeria. The research concluded that tax incentive plays a vital role in ensuring that small and medium enterprises thrive in Nigeria. Also, [10] examined the impact of tax revenue on the Nigerian economy using Ordinary least square of multiple regression model. The study concluded that there no significant relationship between company income tax and the growth of the Nigeria economy. Similary [11] carried out an empirical analysis on the relationship between taxation and economic growth in Nigeria. The result of the study was that Petroleum profit tax, and Company Income tax had a positive relationship with Real Gross Domestic Product while that of Custom and Excise duties was negative. Also, all the tax components do not significantly affect the economic growth in Nigeria. In a study the nexus of taxation and economic growth in Nigeria by [4] the study stated that taxes have a positive relation with economic growth. While [12] concluded that increase in tax incentives does not bring about a corresponding increase in foreign direct investment in Nigeria.

In a study [1] to examine the relationship of taxation and economic growth in Africa from the period 2004 to 2013, the findings for this study indicated that tax revenue is positively related to GDP and promotes economic growth in Africa. While [15] using a sub-Saharan African data have found out that tax policy variables like distortionary tax has negative 
impact but insignificant impact on economic growth while non-distortionary taxes has a positive impact but insignificant effect economic growth rate. Similarly,[14] investigated the impact of tax incentives on the industrial growth of SubSahara African States using Nigeria and Ghana as case studies. The study employed the Ordinary Least Square technique. The result indicates 0.529:1 relationship between tax incentives and GDP. The study concluded although the relationship is positive that African countries are not doing much to get the positive effect of tax incentives on economic growth. In South Africa, [6] in examining the Impact of Taxation on Economic Growth in South Africa for the period 1981 - 2016 using the Auto-Regressive Distribution Lag (ARDL) approach. The empirical results confirmed that there is a negative relationship between tax revenue and economic growth in South Africa. Also [13], in a study Optimal tax rate and economic growth. evidence from Nigeria and South Africa concluded that that higher taxes are strongly correlated with reduced economic growth in the two countries.

In Turkey, [2] examined tax policies the period 1980-2014 for the Turkish economy in the light of Laffer curve theory. The outcome of the study concluded that many times, Turkey implemented inappropriate tax policies and collected more tax revenues. Using a sample of 17 Organisation for Economic Co-operation (OECD) countries [7\} studied the impact of taxation on economic development and sophistication in these countries it concluded that there is a negative impact of capital taxes on economic sophistication when countries become more economically stronger. In Jordan [9] concluded that consumption tariffs and taxes has a positive influence on economic growth. In the United States of America, [12] posit that taxes sometimes cannot influence business decisions of companies because of their ability to pass on the tax burden the consumers. This therefore diminishes the role of taxation on business decisions; hence businesses are not always sensitive to tax policies. Also, [8] using data from OECD Countries concluded that there is a negative relationship between economic growth and corporate taxes, value added tax and personal income taxes in these countries.

The empirical studies considered above showed the divergent results from negative to positive. Hence, there is no consensus on the of the linkage between taxation and economic growth in Nigeria and other countries.

\section{Research Methodology}

This section deals with the method employed to obtain relevant information

\section{Data Source and Descriptions}

The ex-post facto research design was adopted. Secondary data for a period of 8 years covering 2011 to 2018 were obtained from Federal Inland Revenue Service and Central Bank of Nigeria.

\section{Model Specification}

This research model was underpinned by the Ibn Khaldun"s theory of taxation and its modern equivalent Laffer curve theory of taxation" which seeks to achieve the optimal tax rate. The research adapted the model by used by [15].

The model used in this study is an econometric model, which runs a multiple regression analysis between real gross domestic product (dependent variable) and the taxation collection and incentives variables that affect economic growth such as tax revenue, foreign direct investment equity, foreign direct investment other capital which measures incentives (independent variables).

$$
\text { Real } G D P=(T A X R, F D I, \text { FDIC })
$$

GDP is the Real Gross Domestic Product measuring economic growth

TAXR is measuring total Tax Revenue collected

FDI is the foreign direct investment equity

FDIC means the foreign direct investment other capital

$$
\mathrm{GDP}=\mathrm{a}+\beta \mathrm{i}, T A X R+\beta 2 F D I+\beta 3 \mathrm{FDIC}+\mathrm{e}
$$

$\mathrm{a}=$ intercept

$\beta i, \beta 2 \beta 3=$ Regression coefficients

$\mathrm{e}=$ error term

\section{Model Estimation Procedure}

The first step in the pre-estimation stage is the use of descriptive statistics in order to understand the nature of the data. This helps to determine if the data are normally dispersed through their mean. The next step is the correlation matrix and variance inflation factor tests to check for the existence of autocorrelation and multicollinearity among the independent variables. The last step is to determine the stationarity of the series and also to predict the existence of a long-run relationship between the dependent variable and the independent variables.

\section{Data Presentation Analysis and Findings}

Table 1. Descriptive Statistics of Variables

\begin{tabular}{lllll}
\hline & GDP & TAXR & FDI & FDIC \\
\hline Mean & 65382316 & 4444.270 & 1534.051 & 1484.000 \\
Median & 67542011 & 4671.550 & 2292.470 & 9.335000 \\
Maximum & 69799942 & 5320.520 & 1038.700 & 254.4400 \\
Minimum & 57511042 & 3307.500 & 434.6486 & 2.320000 \\
Std. Dev. & 4604953. & 684.7196 & 0.525185 & 86.51177 \\
Skewness & -0.740134 & -0.458103 & & 2.000171 \\
\hline
\end{tabular}




\begin{tabular}{lllll}
\hline & GDP & TAXR & FDI & FDIC \\
\hline Kurtosis & 1.977483 & 1.973713 & 2.218169 & 5.387623 \\
Jarque-Bera & 1.078911 & 0.630900 & 0.571512 & 7.234495 \\
Probability & 0.583066 & 0.729461 & 0.751446 & 0.026857 \\
Sum & $5.23 \mathrm{E}+08$ & 35554.16 & 12272.41 & 380.4400 \\
Sum Sq. Dev. & $1.48 \mathrm{E}+14$ & 3281887. & 1322436. & 52390.01 \\
Observations & 8 & 8 & 8 & 8 \\
\hline
\end{tabular}

The table reveals that for the nine-year period under review, the average real GDP was $65,382,316$ with a minimum value of 57511042 and maximum of 69799942 attributed to the rebase of Nigerian GDP in 2013 and high inflation 2016-2017, The distribution of all the GDP and tax $\mathrm{T}$ variables are negatively skewed.

Regression Analysis

The main estimation tests conducted were the OLS

Table 2. Regression Result.

\begin{tabular}{|c|c|c|c|c|}
\hline \multicolumn{5}{|c|}{ Dependent Variable: GDP } \\
\hline \multicolumn{5}{|c|}{ Method: Least Squares } \\
\hline \multicolumn{5}{|l|}{ Sample: 20112018} \\
\hline \multicolumn{5}{|c|}{ Included observations: 8} \\
\hline Variable & Coefficient & Std. Error & t-Statistic & Prob. \\
\hline TAXR & -180.2058 & 1834.851 & -0.098213 & 0.9265 \\
\hline FDI & -2738.487 & 2828.763 & -0.968086 & 0.3878 \\
\hline FDIC & -43125.18 & 12561.68 & -3.433074 & 0.0265 \\
\hline $\mathrm{C}$ & 72434996 & 7012230. & 10.32981 & 0.0005 \\
\hline R-squared & 0.789492 & Mean dependent var & & 65382316 \\
\hline Adjusted R-squared & 0.631610 & S. D. dependent var & & 4604953. \\
\hline S. E. of regression & 2794981. & Akaike info criterion & & 32.83140 \\
\hline Sum squared residual & $3.12 \mathrm{E}+13$ & Schwarz criterion & & 32.87112 \\
\hline Log-likelihood & -127.3256 & Hannan-Quinn criter. & & 32.56350 \\
\hline F-statistic & 5.000542 & Durbin-Watson stat & & 1.773868 \\
\hline Prob (F-statistic) & 0.077006 & & & \\
\hline
\end{tabular}

Source: EViews 9 output

\section{Estimation Equation:}

$\mathrm{GDP}=\mathrm{C}(1) * \mathrm{TAXR}+\mathrm{C}(2) * \mathrm{FDI}+\mathrm{C}(3) * \mathrm{FDIC}+\mathrm{C}(4)$ Equati on4
TAXR: Tax collected

FDI: Foreign Direct Investment - Equity

FDIC: Foreign Direct Investment - Other capital Substituted Coefficients:

Where:

GDP: TOTAL_GDP

$$
\text { GDP }=-180.2057 * \text { TAXR }-2738.4867 * \text { FDI }-43125.1801 * \text { FDIC }+72434996.3308
$$

As observed from the regression models selected above it was observed that TAXR is explaining GDP at 180.2057 units with a p-value of 0.9265 , which is greater than the $5 \%$ level of significance. Thus, a unit increase TAXR will imply a direct decrease in GDP. Since the pvalue is greater than $0.05(5 \%)$ level of significance, the finding cannot be generalized at a $95 \%$ level of confidence. Also, the FDI is has a coefficient of - 2738.4867 in impacting GDP. Thus, a unit increase FDI will imply a direct decrease in GDP. Since the p-value 0.3878 is greater than $0.05(5 \%)$ level of significance, the finding cannot be generalized at a $95 \%$ level of confidence. Lastly, there is also a negative relationship between FDIC and GDP since the FDIC coefficient is observed to be 43125.1801. Although the p-value of 0.0265 is less than $0.05(5 \%)$ level of significance. Thus, the findings can be generalized for the relationship between the variables over the study periods. Furthermore, the R-square adjusted of $0.6316 \%$ shows that the independent variables are explaining the dependent variable GDP at $63.16 \%$, leaving other $37 \%$ to other extraneous variables.

Durbin-Watson test for serial correlation with any figure close to 2.0 said to be a sign of no serial correlation. At 1.77 we can conveniently state that there is no sign of serial correlation in the data

Multicollinearity Test

Variance inflation factors (VIF) measure how much the variance of the estimated regression coefficients are inflated as compared to when the predictor variables are not linearly related.

Use to describe how much multicollinearity (correlation between predictors) exists in a regression analysis. Multicollinearity is problematic because it can increase the variance of the regression coefficients, making them unstable 
and difficult to interpret.

Table 3. Interpretation of the VIF.

\begin{tabular}{ll}
\hline VIF & Status of predictors \\
VIF $=1$ & Not correlated \\
$1<\mathrm{VIF}<5$ & Moderately correlated \\
$\mathrm{VIF}>5$ to 10 & Highly correlated \\
\hline
\end{tabular}

Table 4. Variance Inflation Factors.

\begin{tabular}{llll}
\hline & Coefficient & Uncentered & Centered \\
\hline Variable & Variance & VIF & VIF \\
TAXR & 3366680. & 69.51249 & 1.414385 \\
FDI & 8001903. & 20.63896 & 1.354597 \\
FDIC & $1.58 \mathrm{E}+08$ & 1.423688 & 1.058245 \\
C & $4.92 \mathrm{E}+13$ & 50.35524 & NA \\
\hline
\end{tabular}

Sample: 20112018

Included observations: 8

As observed in Table 4 the Centered VIF coefficient was obtained and observed to range from 1.0582 to 1.4143 for all the variables (TAXR, FDI, FDIC), which falls within the range $1<\mathrm{VIF}<5$ that implies that there is a presence of moderately correlated explanatory variables in the models to be formulated. Hence, multicollinearity is not a problem of the model formulated.

\section{Serial correlation and heteroskedasticity test}

The R-squared of $0.7894 \%$ indicated that $78.94 \%$ variation in GDP is attributed to TAXR, FDI and FDIC in Nigeria. Also, the diagnostic checks of residual serial correlation, heteroskedasticity and Jarque-Bera residual normality test suggested that the residuals are void of serial correction, and heteroskedasticity and are normality distributed since the pvalues of the test are greater than $0.05(5 \%)$.

Table 5. Breusch-Godfrey Serial Correlation LM Test.

\begin{tabular}{llll}
\hline F-statistic & 4.525929 & Prob. F $(2,2)$ & 0.1810 \\
Obs*R-squared & 6.552280 & Prob. Chi-Square (2) & 0.0378 \\
\hline
\end{tabular}

Table 6. Heteroskedasticity Test: Breusch-Pagan-Godfrey.

\begin{tabular}{llll}
\hline F-statistic & 3.563740 & Prob. F (3, 4) & 0.1257 \\
Obs*R-squared & 5.821828 & Prob. Chi-Square (3) & 0.1206 \\
Scaled explained SS & 0.544707 & Prob. Chi-Square (3) & 0.9090 \\
\hline
\end{tabular}

Discussing of Findings

The finding revealed that there is a negative but not significant relationship between tax revenue and economic growth in Nigeria. These findings have also been supported by [6] in South Africa using autoregressive Distribution Lag (ARDL) approach to co-integration to find the short and long-run relationship between tax revenue and economic growth in the period of 1981 to 2016 the empirical result indicated that the impact of taxes on economic growth is negative and significant in the short and long-run. Also, this collaborates somewhat [15] in a study Effect of distortionary and non-distortionary taxes on economic growth: Evidence from Sub-Saharan African countries confirms that distortionary tax has a negative and insignificant effect on economic growth in Sub-Saharan African countries

The findings also revealed that there is a negative but insignificant relationship between and foreign direct investment equities and the growth of the Nigeria economy. The regression result indicated a negative and significant relationship between the foreign direct investment other capital and the growth of the Nigeria economy. The results of this study corroborate the findings of [7] using a sample of 17 Organisation for Economic Co-operation (OECD countries the findings provide strong evidence that country's capital taxation policy has a negative and statistically strong impact on its productive structure.

This resaerch also shows that there is a negative and significant relationship between foreign direct investment other capital and economic growth. This is in tandem with [12] that stated that increase in tax incentives does not bring about a corresponding increase foreign direct investment

The results of this study confirm certain previous evidence by a number of researchers for the inter-country as well as country studies while not it not tandem with certain findings.

\section{Conclusion and Recommendation}

Taxation as a major role in nation-building According to economic analysis, taxation is a strong socio-political and economical tool for economic growth [10] This research adds to debate on the effectiveness of taxes as a tool for promoting economic growth and development which remain inconclusive. The study objectives were to asses the impact of tax collection and incentives on the economic growth of Nigeria. Several theories underpin the study of taxation; only few can be directly traced to tax incentives and collection specifically Laffer curve theory. We, therefore, anchor this study on the theory. Based on the findings, the study showed that tax revenue has a negative and but insignificant impact on the economic growth. Also, foreign direct investment equities have a negative and insignificant effect on economic growth. While empirical results confirm that there is a negative and significant relationship foreign direct investment, other capital and economic growth in Nigeria. Given findings the study, it therefore recommended to economic policymakers in Nigeria that they should improve on the mechanisms for the collection of taxes to stimulate economic growth. It apparent from this research the tax revenue has not impacted on real GDP. The Government should grant more incentives to those sectors monitor such incentives as well as gathering relevant data of the actual amount of incentives given relative to the economic growth in other to evaluate the efficiency of tax incentives in the Nigerian economy. There is also the need to improve on the tax drive now that revenue from the oil and gas sector is declining. Increasing tax incentives in the productive sectors would go a long way in reducing the cost of production thereby increasing the productivity in these sectors because of the positive multiplier effects on the economic growth of Nigeria. 


\section{References}

[1] Babatunde, O. A., Ibukun, A. O., \& Grace, O. O. (2017). Taxation revenue and economic growth in Africa. Journal of Accounting and Taxation, 9 (2), 11-22. doi: 10.5897/JAT2016.023.

[2] Dergisi, U. S. (2017). he Application of the Laffer Curve in the economy of Turkey. The Journal of International Social Research, 10 (50), 654-659.

[3] Feyitimi, O., Temitope, O. A., Akeem, L. B., \& Oladele, O. S. (2016). Tax Incentives And the Growth of Small And Meduim Scale Enterprises In Developing Economy: The Nigerian Experience. European Journal of Research and Reflection in Management Science, 4 (2), 24-42.

[4] Gabriel, E. D., \& Ezekiel, A. I. (2019). The Nexus between Tax Revenue and Economic Growth in Nigeria. International Journal of Applied Economics, Finance and Accounting, 4 (2), 45-55.

[5] Islahi, A. A. (2006). Ibn Khaldun's Theory of Taxation and Its Relevance Today. The Islamic Research and Training Institute (pp. 1-24). Madrid: Islamic Cultural Centre of Madrid. doi: 10.15238/tujise.2015.2.2.1-19

[6] Khumbuzile, D., \& Khobai, H. (2018). The impact of Taxation on Economic Growth in South Africa. Munich: Munich Personal RePEc Archive.

[7] Lapatinas, A., Kyriakou, A., \& AntoniosGaras. (2019). Taxation and economic sophistication: Evidence from OECD countries. PLoS One, 14 (3), 1-21.

[8] Macek, R. (2014). The Impact of Taxation on Economic Growth: Case Study of OECD Countries. Review of Economic Perpectives, 14 (4), 309-328.

[9] Mdanat, M. F., Shotar, M., Samawi, G., Mulot, J., Arabiyat, T. S., \& Alzyadat, M. A. (2018). Tax structure and economic growth in Jordan, 1980-2015. EuroMed Journal of Business, $1,102-127$.

[10] Ojong, C. M., Anthony, O., \& Arikpo, O. F. (2016). The Impact of Tax Revenue on Economic Growth: Evidence from Nigeria. Journal of Economics and Finance, 7 (1), 32-38.

[11] ONAKOYA, A. B., \& AFINTINNI, O. I. (2016). Taxation And Economic Growth In Nigeria. Asian Journal of Economic Modelling, 4 (4), 199-210.

[12] Peters, G. T., \& Bariyima D. Kiabel. (2015). Tax Incentives and Foreign Direct Investment in Nigeria. Journal of Economics and Finance, 6 (5), 10-20.

[13] Prillaman, S. A., \& Meier, K. J. (2014). Taxes, Incentives, and Economic Growth: Assessing the Impact of Pro-business Taxes on U.S. State Economies. The Journal of Politics, 76 (2), 364-379.

[14] SAIBU, O. M. (2015). Optimal tax rate and economic growth. Evidence from Nigeria and South Africa. E u ro E co $n$ o $m i$ c a, 1 (34), 41-50.

[15] Siyanbola, T. T., Adedeji, S., Adegbie, F. F., \& Rahman, M. M. (2017). Tax incentives and industrial/economic growth of subSaharan African States. Journal of Advanced Research in Business and Management Studies, 7 (2), 78-90. Retrieved October 25, 2019

[16] Ugwunta, O. D., \& Ugwuanyi, U. B. (2015). Effect of distortionary and non-distortionary taxes on economic growth: Evidence from Sub-Saharan African countries. Journal of Accounting and Taxation, 7 (6), 106-112. 